\title{
Seroprevalence of hepatitis $C$ virus among people living with HIV/AIDS in Latin America and the Caribbean: a systematic review
}

Fatima Mitiko Tengan ${ }^{1,2^{*}}$, Karim Yakub Ibrahim ${ }^{1,2}$, Bianca Peixoto Dantas ${ }^{2}$, Caroline Manchiero ${ }^{2}$, Mariana Cavalheiro Magri ${ }^{2}$ and Wanderley Marques Bernardo 3,4

\begin{abstract}
Background: Studies have shown that the immunosuppression induced by the human immunodeficiency virus (HIV) accelerates the natural history of liver disease associated with hepatitis C virus (HCV), with 3- to 5 -fold higher odds of coinfected individuals developing cirrhosis. However, estimates of the seroprevalence of hepatitis $\mathrm{C}$ among people living with HIV/acquired immune deficiency syndrome (AIDS) (PLHA) in Latin America and the Caribbean (LAC) are widely variable.

Methods: We performed a systematic review to estimate the seroprevalence of HCV among PLHA. We searched studies on HIV and HCV infections in LAC included in the PubMed, LILACS and Embase databases in December of 2014 with no time or language restrictions. The following combinations of search terms were used in the PubMed and Embase databases: (HIV OR Acquired Immunodeficiency Syndrome Virus OR AIDS OR HTLV OR Human Immunodeficiency Virus OR Human T Cell) AND (HCV OR HEPATITIS C OR HEPATITIS C VIRUS OR HEPACIVIRUS) AND (name of an individual country or territory in LAC). The following search terms were used in the LILACS database: (HIV OR AIDS OR Virus da Imunodeficiencia Humana) AND (HCV OR Hepatite C OR Hepacivirus). An additional 11 studies were identified through manual searches. A total of 2,380 publications were located, including 617 duplicates; the remaining articles were reviewed to select studies for inclusion in this study.

Results: A total of 37 studies were selected for systematic review, including 23 from Brazil, 5 from Argentina, 3 from Cuba, 1 from Puerto Rico, 1 from Chile, 1 from Colombia, 1 from Mexico, 1 from Peru and 1 from Venezuela. The estimated seroprevalence of HCV infection varied from 0.8 to $58.5 \%$ (mean 17.37; median 10.91), with the highest in Argentina and Brazil and the lowest in Venezuela and Colombia.

Conclusions: Investigation of HCV infection among PLHA and of HIV infection among people living with HCV is highly recommended because it allows for better follow up, counseling and treatment of HIV/HCV-coinfected patients. Future studies with larger sample sizes are needed in both South and Central America to understand and address the risk factors associated with the acquisition of infection.
\end{abstract}

Keywords: Hepatitis C, HCV, HIV, Coinfection, Seroprevalence, Latin America, Caribbean

\footnotetext{
* Correspondence: fatima.tengan@uol.com.br

${ }^{1}$ Department of Infectious and Parasitic Diseases, School of Medicine,

University of São Paulo (Universidade de São Paulo - USP), São Paulo, Brazil

${ }^{2}$ Laboratory of Viral Medical Research in Hepatology (Laboratório de

Investigação Médica em Hepatologia por vírus - LIM-47), Clinical Hospital,

School of Medicine, USP, São Paulo, Brazil

Full list of author information is available at the end of the article
} 


\section{Background}

Approximately 2.2 to $3.0 \%$ of the world's population (130-170 million people) is infected with the hepatitis $C$ virus $\mathrm{C}(\mathrm{HCV})$, and approximately 36.7 million people live with human immunodeficiency virus infection/acquired immune deficiency syndrome (HIV/AIDS) $[1,2]$. The occurrence of coinfection has been reported because $\mathrm{HCV}$ and HIV share the same transmission mechanisms.

Although HIV/HCV-coinfected individuals do not seem to have an increased risk of AIDS, kidney disease or heart disease, their odds of developing cirrhosis are higher [3]. $\mathrm{HCV}$ infection increases the number of deaths due to liver disease among coinfected individuals but does not influence the virological or immunological responses to highly active antiretroviral therapy (HAART) [4].

There is evidence that HIV may negatively influence the progression of $\mathrm{HCV}$-related liver disease. According to one meta-analysis [5], the prevalences of cirrhosis in populations of HIV-infected individuals 20 and 30 years after HCV infection were $21 \%$ (95\% CI: 16-28 \%) and $49 \%$ (95 \% CI: 40-59\%), respectively. Other studies [6, 7] found that HIV-induced immunosuppression accelerated the natural history of HCV-related liver disease and that the odds of coinfected patients developing cirrhosis were 3- to 5-fold higher.

Additionally, the odds of hepatotoxicity due to HAART are higher among $\mathrm{HIV} / \mathrm{HCV}$ coinfected patients than in individuals with HIV monoinfection [8].

In contrast to the situation in Europe and the United States, few data are available concerning HCV/HIV coinfection in Latin America and the Caribbean (LAC) despite their relevance for the formulation of public health policies. The aim of the present study was to investigate the seroprevalence of $\mathrm{HCV}$ infection among people living with HIV/AIDS (PLHA) in LAC.

\section{Methods}

We performed a systematic review of published studies on the seroprevalence of $\mathrm{HCV}$ infection among PLHA in countries and/or territories in LAC. The review was performed and described following the "PRISMA" (Preferred Reporting Items for Systematic Reviews and Meta-Analysis) Statement published in 2009 [9].

\section{Search strategies}

We searched all studies on HIV and HCV infection in LAC included in the PubMed, LILACS (Literatura LatinoAmericana e do Caribe em Ciências da Saúde/Latin American and Caribbean Health Sciences Literature) and Embase databases in December of 2014 with no time or language restrictions. The following combinations of search terms were used in the PubMed and Embase databases: (HIV OR Acquired Immunodeficiency Syndrome Virus OR AIDS OR HTLV OR Human Immunodeficiency
Virus OR Human T Cell) AND (HCV OR HEPATITIS C OR HEPATITIS C VIRUS OR HEPACIVIRUS) AND (name of an individual country or territory in LAC). The following search terms were used in the LILACS database: (HIV OR AIDS OR Virus da Imunodeficiencia Humana) AND (HCV OR Hepatite C OR Hepacivirus). The keywords were used as "text" (all fields) in the databases. We performed a manual search of the references cited in the selected studies and review articles to detect additional relevant publications. All instances of disagreement in the identification of relevant publications were discussed until a consensus was reached. To achieve this consensus, the researchers responsible for each phase review spoke either in person or by phone to present their arguments. If the disagreement persisted, the references in question were selected for the next phase of the study.

The titles and abstracts of the located publications were independently analyzed by 2 examiners (KYI and $\mathrm{BPD})$, resulting in a list of potentially relevant studies. The full texts of these articles were analyzed for inclusion in the systematic review.

Articles describing data on HIV/HCV coinfection with a serologic diagnosis of HIV and HCV infection that reported estimates of the prevalence of anti-HIV/anti$\mathrm{HCV}$ antibodies among HIV-infected individuals were included in the review.

\section{Study selection}

We included original articles reporting the seroprevalence of antibodies against HCV (anti-HCV) among PLHA in $\mathrm{LAC}$ in the review provided that the number of participants was 50 or larger. We did not include case reports, case series, review articles, comments, or studies whose participants did not reside in LAC or had been described in previous publications. In the case of multiple studies performed on the same population, only the most complete data were included in the study. We also excluded self-reported HIV and/or $\mathrm{HCV}$ infection, data resulting from mandatory reporting of HIV and/or HCV infection (e.g., databases of national health ministries), specific groups of PLHA (e.g., drug users and homeless) and data from clinical trial or therapeutic studies.

The following definitions were used in the present review: (1) HIV infection: presence of anti-HIV antibodies based on immunoenzymatic methods; (2) HCV infection: presence of anti-HCV antibodies based on the immunoenzymatic method or immunoblotting; and (3) LAC: the following countries and territories - Argentina, Bolivia, Brazil, Chile, Colombia, Ecuador, French Guiana, Guyana, Paraguay, Peru, Suriname, Uruguay, Venezuela, Belize, Costa Rica, El Salvador, Guatemala, Honduras, Mexico, Nicaragua, Panama, Aruba, Antigua and Barbuda, Aruba, Bahamas, Barbados, Bonaire, British Virgin Islands, Cayman Islands, Cuba, Curaçao, Dominica, Dominican 
Republic, Grenada, Guadalupe, Haiti, Jamaica, Martinique, Montserrat, Puerto Rico, Saba, Saint Barthélemy, Saint Kitts and Nevis, Saint Lucia, Saint Martin, Saint Vincent and the Grenadines, Sint Eustatius, Sint Maarten, Trinidad and Tobago, Turks and Caicos Islands and the United States Virgin Islands.

\section{Data extraction}

The data were independently collected by 2 examiners (MCM and CM); instances of disagreement were solved by discussion and consensus. The following data were extracted from the selected articles: author, year of publication, country, period of data collection, type of study, investigated population, sample size, average age, participants' genders, seroprevalence of $\mathrm{HCV}$, and method used to establish the hepatitis $\mathrm{C}$ diagnosis.

Some articles did not report all of the seroprevalencerelated variables; in these cases, the missing data were calculated based on the reported values (e.g., the numerator was calculated from the reported denominator and seroprevalence).

\section{Assessment of the quality of the studies}

Based on the criteria formulated by Boyle [10], Fowkes \& Fulton [11], Loney [12] and Prins [13], we elaborated a list of criteria to assess the adequacy of the following aspects: sampling (11 items: study design, prospective data collection, definition of the target population, probabilistic sampling, sample size calculation, inclusion and exclusion criteria, specified data collection period, specified age variation, participant selection, acceptable losses, and representative sample), data collection (4 items: standardized data collection, clear defined outcomes, clear description of the outcome detection method, and valid method for outcome diagnosis), and data analysis and description (6 items: description of statistical analysis, total number of participants, number of events (outcome), prevalence by age and gender, prevalence including confidence intervals, and satisfactory confidence intervals). The total number of items was 21 . The items were scored as positive or negative without relevance weighting. Larger scores (positive responses) corresponded to studies with better quality relative to the aims of the present review. The quality of the studies was independently assessed by 2 examiners (KYI and BPD).

\section{Results}

A total of 2,369 articles was located in the investigated databases (PubMed, LILACS and Embase), and an additional 11 articles were identified through a manual search of the references cited in the selected studies and review articles (Fig. 1). Following the exclusion of duplicates (617), 1,753 articles remained for the abstract analysis. Review of the abstracts led to the exclusion of 1,668 articles. Thus, 95 articles were selected for the full-text analysis, of which 37 ( $n=21,383$ individuals) published from 1992 to 2014 were included in the systematic review.

Among these 37 studies on the seroprevalence of HCV infection among PLHA [14-50], 23 studies were conducted in Brazil, 5 in Argentina, 3 in Cuba, 1 in Puerto Rico, 1 in Chile, 1 in Colombia, 1 in Mexico, 1 in Peru and 1 in Venezuela (Table 1). The sample size

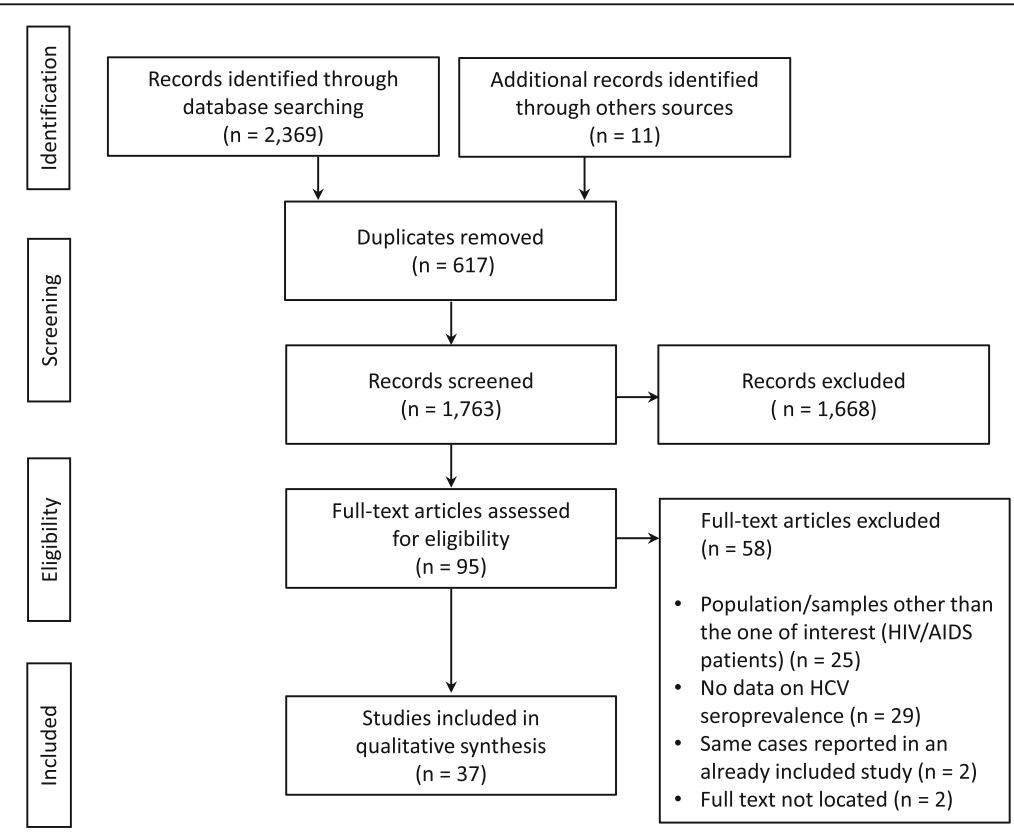

Fig. 1 Flowchart of the identification, inclusion, and exclusion of the studies 
Table 1 Seroprevalence studies of hepatitis C virus (HCV) in people living with HIV/AIDS in Latin America and the Caribbean

\begin{tabular}{|c|c|c|c|c|c|c|c|c|}
\hline Author & Year & Location & Gender & $\begin{array}{l}\text { Mean age } \\
\text { (years) }\end{array}$ & $\begin{array}{l}\text { Data } \\
\text { collection }\end{array}$ & $\begin{array}{l}\text { Sample } \\
\text { size }\end{array}$ & $\begin{array}{l}\text { Anti-HCV detection } \\
N(\%)\end{array}$ & $\begin{array}{l}\text { ELISA kit } \\
\text { generation }\end{array}$ \\
\hline Freitas [14] & 2014 & BRAZIL & $M / F$ & 41.6 & $P$ & 848 & $59(7.0 \%)$ & NA \\
\hline Librelotto [15] & 2014 & BRAZIL & $M / F$ & 41.9 & $\mathrm{R}$ & 148 & 16 (10.8\%) & NA \\
\hline Jaspe [16] & 2014 & VENEZUELA & $M / F$ & NA & $\mathrm{R}$ & 418 & $3(0.7 \%)$ & 3th generation \\
\hline Simon [17] & 2014 & BRAZIL & $M / F$ & 40.6 & $P$ & 580 & 138 (23.8 \%) & 3th generation \\
\hline Távora [18] & 2013 & BRAZIL & $M / F$ & NA & $\mathrm{R}$ & 329 & $23(7.0 \%)$ & NA \\
\hline Brunetta [19] & 2013 & BRAZIL & $M / F$ & NA & $\mathrm{R}$ & 701 & 146 (20.8 \%) & NA \\
\hline Farias [20] & 2013 & ARGENTINA & $M / F$ & 39.2 & $\mathrm{R}$ & 238 & $62(26.0 \%)$ & NA \\
\hline Oliveira-Filho [21] & 2012 & BRAZIL & $M / F$ & 38.1 & $\mathrm{R}$ & 768 & 52 (6.8 \%) & 3th generation \\
\hline Victoria [22] & 2010 & BRAZIL & $M / F$ & 38.5 & R & 1,582 & 70 (4.4 \%) & NA \\
\hline Wolff [23] & 2010 & BRAZIL & $M / F$ & 40.3 & $\mathrm{R}$ & 1,143 & 357 (31.2 \%) & 3th generation \\
\hline Guimarães [24] & 2010 & BRAZIL & $M / F$ & 41.6 & R & 110 & 10 (9.1%) & 3th generation \\
\hline Santos [25] & 2010 & BRAZIL & $M / F$ & 33.8 & $\mathrm{R}$ & 250 & 78 (31.2 \%) & NA \\
\hline Perez [26] & 2010 & PUERTO RICO & $M / F$ & NA & $P$ & 1,650 & 86 (5.2 \%) & NA \\
\hline Sampaio [27] & 2009 & BRAZIL & $M / F$ & 39.3 & $P$ & 429 & 46 (10.7\%) & 3th generation \\
\hline Pérez [28] & 2009 & CHILE & $M / F$ & 40.9 & $\mathrm{R}$ & 273 & 7 (2.6 \%) & NA \\
\hline Carvalho [29] & 2009 & BRAZIL & $M / F$ & NA & $P$ & 343 & $14(4.1 \%)$ & 3th generation \\
\hline Ré [30] & 2008 & ARGENTINA & $M / F$ & NA & $P$ & 310 & 39 (12.6 \%) & NA \\
\hline Carmo [31] & 2008 & BRAZIL & $M / F$ & NA & $R$ & 824 & 76 (9.2 \%) & 3th generation \\
\hline Reiche [32] & 2008 & BRAZIL & $M / F$ & NA & $P$ & 757 & $159(21.0 \%)$ & NA \\
\hline dos Santos [33] & 2008 & BRAZIL & $M / F$ & NA & $P$ & 299 & 10 (3.3 \%) & 3th generation \\
\hline Alfonso [34] & 2008 & CUBA & $M / F$ & NA & R & 90 & $18(20.0 \%)$ & NA \\
\hline Mussi [35] & 2007 & BRAZIL & $M / F$ & 37.2 & P & 1,008 & 110 (10.9\%) & NA \\
\hline Quarleri [36] & 2007 & ARGENTINA & $M / F$ & 39 & $P$ & 593 & $129(21.8 \%)$ & 3th generation \\
\hline Rivas-Estilla [37] & 2007 & MEXICO & $M / F$ & 34 & $P$ & 140 & 17 (12.1\%) & 3th generation \\
\hline Hoyos-Orrego [38] & 2006 & COLOMBIA & $M / F$ & 37.9 & $P$ & 251 & 2 (0.8 \%) & 2th generation \\
\hline Tovo [39] & 2006 & BRAZIL & $M / F$ & 34.4 & $\mathrm{R}$ & 330 & $126(38.2 \%)$ & 3th generation \\
\hline de Carvalho [40] & 2006 & BRAZIL & $M / F$ & NA & $P$ & 343 & $14(4.1 \%)$ & 3th generation \\
\hline Bello Corredor [41] & 2005 & CUBA & NA & NA & $\mathrm{R}$ & 2,994 & $314(10.4 \%)$ & NA \\
\hline Rodriguez [42] & 2005 & CUBA & $\mathrm{F}$ & 29 & $\mathrm{R}$ & 60 & $5(8.4 \%)$ & NA \\
\hline de los Angeles Pando [43] & 2004 & ARGENTINA & $M / F$ & 36.7 & R & 165 & $53(30.5 \%)$ & 3th generation \\
\hline Segurado [44] & 2004 & BRAZIL & $M / F$ & NA & $P$ & 495 & $179(36.2 \%)$ & 3th generation \\
\hline Pavan [45] & 2003 & BRAZIL & $M / F$ & 30.8 & $P$ & 232 & $119(53.8 \%)$ & 2th generation \\
\hline Mendes-Corrêa [46] & 2001 & BRAZIL & $M / F$ & 34.08 & $\mathrm{R}$ & 1,457 & $258(17.7 \%)$ & 2th generation \\
\hline Treitinger [47] & 1999 & BRAZIL & NA & NA & $\mathrm{R}$ & 93 & $50(53.8 \%)$ & NA \\
\hline Fainboim [48] & 1999 & ARGENTINA & $M / F$ & 29 & $P$ & 484 & $283(58.5 \%)$ & NA \\
\hline Edelenyi-Pinto [49] & 1993 & BRAZIL & $M / F$ & NA & $\mathrm{R}$ & 187 & $28(15.0 \%)$ & 1th generation \\
\hline Hyams [50] & 1992 & PERU & $M / F$ & NA & $\mathrm{R}$ & 305 & $13(4.3 \%)$ & NA \\
\hline
\end{tabular}

$M$ male, $F$ female, $P$ prospective, $R$ retrospective, $N A$ not available

varied from 60 to 2,994. Prospective data collection was performed in 16 studies (43.24 \%). Diagnosis of HCV infection was established based on anti-HCV antibody detection using enzyme-linked immunosorbent assay (ELISA) 3 in 15 studies (40.54 \%), ELISA2 in 3 studies
(8.11\%), ELISA1 in 1 study (2.70 \%) and (unspecified) ELISA in 18 studies (48.69\%). The average quality score was 10.76 (variation: 4-18), with 7 studies scoring 7 points or less, 26 scoring 8 to 14 points and 4 scoring 15 to 21 points. The most common cause of impaired 
quality scores was the methods used for sampling (more detailed data on the assessment of the quality of studies are available in the Additional files 1 and 2).

The estimated seroprevalence of $\mathrm{HCV}$ infection in the 37 selected studies from the LAC region varied from 0.7 to $58.5 \%$ (mean 17.4; median 10.9) (Table 1). The highest prevalence was found in studies from Argentina and Brazil and the lowest from Venezuela and Colombia (Table 2).

Most of the selected studies were performed in Brazil. Figure 2 shows the geographic distribution of PLHA coinfected with HCV in Brazil described in these studies. Notably, the southern region had $30 \%$ of all cases [15, $17,23,25,32,39,47]$, followed by the southeast $(25.4 \%)$ $[19,24,44-46,49]$ and midwest $(8.9 \%)[14,35]$ regions (Fig. 2).

\section{Discussion}

$\mathrm{HCV}$ infection is a significant cause of increased morbidity and mortality among individuals living with HIV/ AIDS and other populations of immunodeficient patients as a whole. If we consider that 1 out of 10 individuals living with HIV/AIDS also has hepatitis $C$, there are $175,000 \mathrm{HIV} / \mathrm{HCV}$ coinfected individuals in LAC (based on 1,750,000 individuals living with HIV/AIDS). By summarizing the results of several studies, we attempted to present a comprehensive summary of the literature on the subject and to gain a new understanding of the distribution of anti-HCV among PLHA.

Our systematic review of the prevalence of hepatitis C among individuals living with HIV/AIDS included reports from 37 studies corresponding to 21,383 participants residing in the LAC region. Our main findings included the wide heterogeneity in the information concerning the subject of interest, with the relevant studies conducted in only 9 countries, most of which were in South America. Our review showed that the mean LAC regional seroprevalence of hepatitis $\mathrm{C}$ among PLHA was

Table 2 Seroprevalence of HCV infection in the general population and PLHA by country

\begin{tabular}{|c|c|c|}
\hline Country & $\begin{array}{l}\text { Seroprevalence of HCV in } \\
\text { general population }[1,63](\%)\end{array}$ & $\begin{array}{l}\text { Seroprevalence }{ }^{\mathrm{a}} \text { of HCV } \\
\text { in HIV patients (\%) }\end{array}$ \\
\hline Argentina & 1.9 & 29.9 \\
\hline Brazil & 1.4 & 18.9 \\
\hline Chile & 0.8 & 2.6 \\
\hline Colombia & 1.0 & 0.8 \\
\hline Cuba & 1.8 & 12.9 \\
\hline Mexico & 1.0 & 12.1 \\
\hline Peru & 1.0 & 4.3 \\
\hline Puerto Rico & 6.3 & 5.2 \\
\hline Venezuela & 0.9 & 0.7 \\
\hline
\end{tabular}

${ }^{a}$ Mean seroprevalence found in the selected studies approximately $17.4 \%$. The substantial heterogeneity observed in our study suggests that caution is required when pooled estimates are used. Because an error can occur in the estimated prevalence when attempting to perform a meta-analysis of very heterogeneous data, a meta-analysis was not performed. Additionally, our findings emphasize the need for surveys to include careful descriptions of the sampling procedures and diagnostic methods.

We were not able to locate any review studies on the seroprevalence of hepatitis C among PLHA specifically in the LAC region. In a large cohort of primarily European HIV-infected individuals, Rockstroh et al. found that $33 \%$ of the patients also exhibited HCV infection. Approximately $25 \%$ of the participants were injection drug users (IDUs). The proportion of IDUs among individuals with hepatitis $C$ was $77.5 \%$. In one study conducted in HIV-infected patients in the United States [51], $16 \%$ of the sample also exhibited HCV infection. Approximately $20 \%$ of the participants were IDUs, of which $72.7 \%$ were $\mathrm{HCV}$-positive. In one study performed in Russia, $91 \%$ of HIV-infected IDUs exhibited anti-HCV antibodies [52]. Similarly, high rates of HIV/ HCV coinfection were found in the United States [53], Australia [54], India [55], northern Vietnam [56] and some regions in China $[57,58]$. In the Swiss HIV Cohort Study, the prevalences of HIV/HCV coinfection among IDUs and homosexual and heterosexual men were 87.7, 3.7 and $6 \%$, respectively [59]. An association between drug use and HIV/HCV coinfection was reported in several studies $[51,59,60]$.

One possible cause for the heterogeneity in the seroprevalence results extracted from the selected studies may be differences in the proportion of IDUs included in the studies; we could not analyze this factor with the available data. According to Nelson et al. [61], the prevalence of HCV infection among IDUs in Latin America is approximately $67 \%$, with a range from 10 to $97 \%$. These authors collected data corresponding to 5 countries [Argentina (54.6 \%), Brazil (63.9\%), Mexico (97.4 \%), Paraguay (9.8\%) and Uruguay (21.9\%)] but were unable to locate sufficient information to estimate the $\mathrm{HCV}$ prevalence in the Caribbean.

The seroprevalence results reported in the studies selected in this systematic review may also be attributed to the different prevalence rates of $\mathrm{HCV}$ among the overall population in the locations where the studies were conducted. It is possible to speculate that the HCV prevalence in target populations (here, PLHA) is higher in locations where the prevalence of HCV among the overall population is also higher, although not all studies selected for this review support this hypothesis. This possibility is a cause for concern because the seroprevalence data included in our review do not include the 


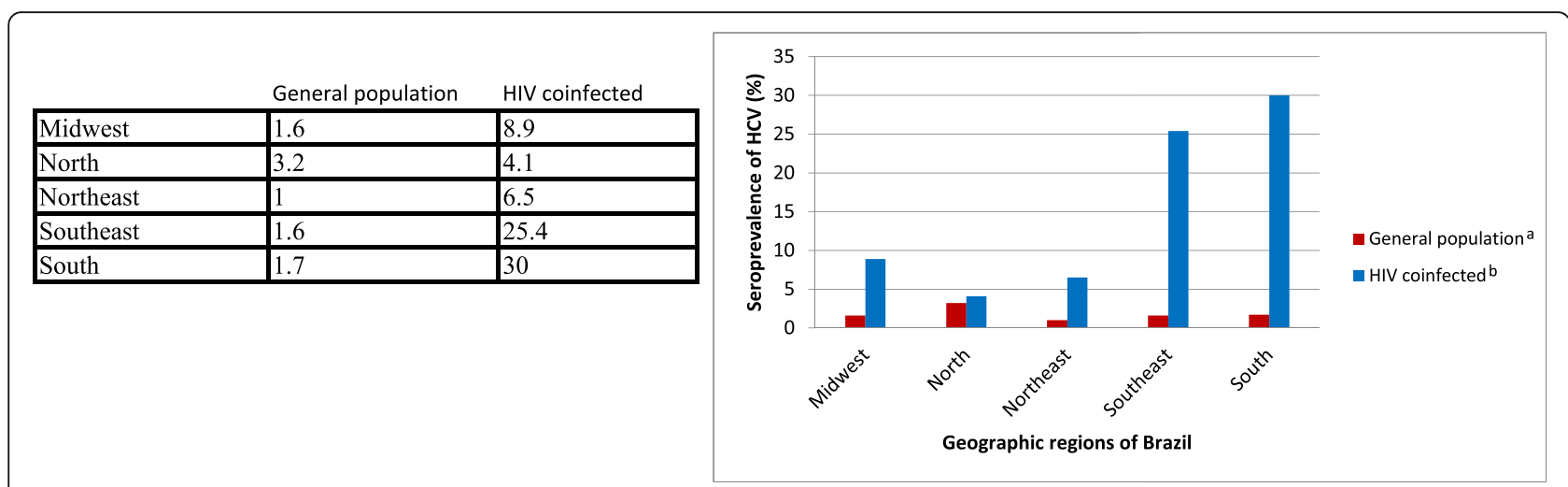

Fig. 2 Seroprevalence of HCV in the general population and in PLHA by geographic region in Brazil. Footnote of Fig. 2: ${ }^{a}$ Based in Pereira et al. [63]; ${ }^{b}$ Median of the HCV seroprevalence found in the selected studies

locations with the highest hepatitis $\mathrm{C}$ prevalence in the LAC region, such as Bolivia (4.7 \%) and Haiti (4.4 \%) [1]. The use of an ELISA method for anti-HCV detection was considered appropriate, but differences in the seroprevalence might be due to the kit used to establish the hepatitis $\mathrm{C}$ diagnosis because the tests might present certain differences in sensitivity and specificity. The third- or fourth-generation immunoenzymatic assays are considered better because they contain $\mathrm{HCV}$ core antigens and $\mathrm{HCV}$ nonstructural genes [62]. Therefore, third- and fourthgeneration ELISAs are more specific diagnostic techniques. When these methods are used, the rate of positive results is lower than that obtained with older methods (first- and second-generation ELISAs).

The seroprevalence of HCV among PLHA seems to be higher than that in the overall population. This finding suggests that preventive measures targeting the overall population do not reduce the prevalence of $\mathrm{HCV}$ or HIV in the previously infected population (HIV or HCV). More direct comparisons should be performed with studies using the same sampling methods and techniques to establish the diagnosis of hepatitis $\mathrm{C}$ in both the overall population and the population of HIV-seropositive individuals.

A limitation of the present study is that the data collection was quite heterogeneous. Most studies used convenience samples, which may not be representative of the population of individuals living with HIV/AIDS. Additionally, we did not analyze the studies per country or territory because they were only conducted in 9 countries (6 in South America, 2 in Central America and 1 in North America).

\section{Conclusions}

The high mean seroprevalence found in the LAC region (17.4 \%) reinforced the recommendation that investigations of HCV infection among PLHA and of HIV infection among individuals with hepatitis $\mathrm{C}$ are highly recommended to allow for better follow up, counseling and treatment of $\mathrm{HIV} / \mathrm{HCV}$-coinfected patients. Future studies with larger sample sizes are needed in both South and Central America to understand and address the risk factors associated with the acquisition of infection.

\section{Additional files}

Additional file 1: Instrument for assessment of the quality of the studies. Description: describes the items considered in the assessment of the quality of the studies. (DOCX $12 \mathrm{~kb}$ )

Additional file 2: Assessment of the quality of the studies Description: contains data corresponding to the quality of the studies that describe their (quality) total score relative to the following items: sampling process, procedures used for data collection, and data analysis and description. (DOC $82 \mathrm{~kb}$ )

\section{Abbreviations}

AIDS: Acquired immune deficiency syndrome; Anti-HCV: Antibodies against HCV; ELISA: Enzyme-linked immunosorbent assay; HAART: Highly active antiretroviral therapy; HCV: Hepatitis C virus; HIV: Human immunodeficiency virus; IDU: Injection drug user; LAC: Latin America and the Caribbean; PLHA: People living with HIV/acquired immune deficiency syndrome

\section{Acknowledgements}

Not applicable

\section{Funding}

The authors declare they did not receive any funding for this research.

\section{Availability of data and materials}

All data analyzed during this study are included in this published article (and its Additional files 1 and 2), and are available from included studies which are fully referenced.

\section{Authors' contributions}

FMT was in charge of the study design, data analysis and interpretation and drafting of the manuscript. KYI and BPD performed the search in the databases and selected articles based on their titles and abstracts. MCM and CM selected the studies included in the review based on a full-text analysis. KYI and BPD assessed the quality of the studies. WMB contributed to the data analysis and interpretation and was in charge of the critical revision of the manuscript content. All authors read and approved the final manuscript.

Competing interests

The authors declare that they have no competing interests. 


\section{Consent for publication}

Not applicable.

\section{Ethics approval and consent to participate}

No ethical approval was sought as it was deemed unnecessary for this systematic review.

\section{Author details \\ 'Department of Infectious and Parasitic Diseases, School of Medicine, University of São Paulo (Universidade de São Paulo - USP), São Paulo, Brazil. ${ }^{2}$ Laboratory of Viral Medical Research in Hepatology (Laboratório de Investigação Médica em Hepatologia por vírus - LIM-47), Clinical Hospital, School of Medicine, USP, São Paulo, Brazil. '3chool of Medicine, USP, São Paulo, Brazil. ${ }^{4}$ Brazilian Medical Association, São Paulo, Brazil.}

\section{Received: 16 January 2016 Accepted: 29 October 2016}

\section{Published online: 09 November 2016}

\section{References}

1. Lavanchy D. The global burden of hepatitis C. Liver Int. 2009;29 Suppl 1:74-81.

2. WHO. Global Health Observatory $(\mathrm{GHO})$ date. http://www.who.int/gho/hiv/ en/. Accessed 7 Nov 2016.

3. Tedaldi EM, Baker RK, Moorman AC, Alzola CF, Furhrer J, McCabe RE, et al. Influence of coinfection with hepatitis $C$ virus on morbidity and mortality due to human immunodeficiency virus infection in the era of highly active antiretroviral therapy. Clin Infect Dis. 2003;36:363-7.

4. Rockstroh JK, Mocroft A, Soriano V, Tural C, Losso MH, Horban A, et al. Influence of hepatitis $C$ virus infection on HIV-1 disease progression and response to highly active antiretroviral therapy. J Infect Dis. 2005;192:9921002.

5. Thein HH, Yi Q, Dore GJ, Krahn MD. Natural history of hepatitis C virus infection in HIV-infected individuals and the impact of HIV in the era of highly active antiretroviral therapy: a meta-analysis. AIDS. 2008;22:1979-91.

6. Graham CS, Baden R, Yu E, Mrus JM, Carnie J, Heeren T, et al. Influence of human immunodeficiency virus infection on the course of hepatitis $C$ virus infection: a meta-analysis. Clin Infect Dis. 2001:33:562-9.

7. Soto B, Sánchez-Quijano A, Rodrigo L, del Olmo JA, García-Bengoechea M, Hernández-Quero J, et al. Human immunodeficiency virus infection modifies the natural history of chronic parenterally-acquired hepatitis $C$ with an unusually rapid progression to cirrhosis. J Hepatol. 1997;26:1-5.

8. Pineda JA, Macías J. Progression of liver fibrosis in patients coinfected with hepatitis $C$ virus and human immunodeficiency virus undergoing antiretroviral therapy. J Antimicrob Chemother. 2005:55:417-9.

9. Moher D, Liberati A, Tetzlaff J, Altman DG, PRISMA Group. Preferred reporting items for systematic reviews and meta-analyses: the PRISMA statement. J Clin Epidemiol. 2009;62:1006-12.

10. Boyle MH. Guidelines for evaluating prevalence studies. Evid Based Mental Health. 1998;1:37-9.

11. Fowkes FG, Fulton PM. Critical appraisal of published research: introductory guidelines. BMJ. 1991;302:1136-40.

12. Loney PL, Chambers LW, Bennett KJ, Roberts JG, Stratford PW. Critical appraisal of the health research literature: prevalence or incidence of a health problem. Chronic Dis Can. 1998;19:170-6.

13. Prins J, Blanker MH, Bohnen AM, Thomas S, Bosch JL. Prevalence of erectile dysfunction: a systematic review of population-based studies. Int J Impot Res. 2002;14:422-32

14. Freitas SZ, Teles SA, Lorenzo PC, Puga MA, Tanaka TS, Thomaz DY, et al. HIV and HCV coinfection: prevalence, associated factors and genotype characterization in the midwest region of Brazil. Rev Inst Med Trop Sao Paulo. 2014;56:517-24

15. Librelotto CS, Simon D, Ikuta N, Lunge VR. Low prevalence of human immunodeficiency virus and hepatitis $\mathrm{C}$ virus co-infection in a medium size city in southern Brazil. Braz J Infect Dis. 2014. doi: 10.1016/j.bjid.2014.05.014

16. Jaspe RC, Sulbarán YF, Loureiro CL, Martínez N, Devesa M, Rodríguez Y, et al. Genetic diversity of hepatitis $B$ virus and hepatitis $C$ virus in human immunodeficiency virus type 1-co-infected patients from Venezuela. J Med Microbiol. 2014;63:1099-104.

17. Simon D, Michita RT, Béria JU, Tietzmann DC, Stein AT, Lunge VR. Alcohol misuse and illicit drug use are associated with HCV/HIV co-infection. Epidemiol Infect. 2014;142:2616-23.
18. Távora LG, Hyppolito EB, Cruz JN, Portela NM, Pereira SM, Veras CM. Hepatitis B, C and HIV co-infections seroprevalence in a northeast Brazilian center. Arq Gastroenterol. 2013;50:277-80.

19. Brunetta DM, de Santis GC, Vilar FC, Brandão RA, Muniz RZ, Lima GM, et al. Hematological particularities and co-infections in injected drug users with AIDS. Braz J Infect Dis. 2013;17:654-6.

20. Farías AA, Kremer LE, Allende L, Díaz Mdel P, Pisano MB, Contigiani MS, et al. Determinants of immunological and virological responses to antiretroviral therapy amongst HIV-infected adults in central Argentina: negative influence of hepatitis C infection. Trans R Soc Trop Med Hyg. 2013;107:432-7.

21. Oliveira-Filho AB, Oliveira EH, Castro JA, Silva LV, Vallinoto AC, Lemos JA. Epidemiological aspects of HCV infection in HIV-infected individuals in Piauí State, Northeast Brazil. Arch Virol. 2012;157:2411-6.

22. Victoria MB, Victoria Fda S, Torres KL, Kashima S, Covas DT, Malheiro A. Epidemiology of HIV/HCV coinfection in patients cared for at the Tropical Medicine Foundation of Amazonas. Braz J Infect Dis. 2010;14:135-40.

23. Wolff FH, Fuchs SC, Barcellos NN, de Alencastro PR, Ikeda ML, Brandão AB, et al. Co-infection by hepatitis C virus in HIV-infected patients in southern Brazil: genotype distribution and clinical correlates. PLoS One. 2010;5:e10494.

24. Guimarães RA, Cunha EM, Aguiar RS, Pereira SE. The positivity of antibodies against the hepatitis $C$ virus (anti-HCV) and of the surface antigen of the hepatitis $B$ virus (AgHBs) in adults infected with the human immunodeficiency virus (HIV). Rev Bras Med. 2010;67:296-8.

25. Santos KF, Vieira TB, Beck ST, Leal DBR. Laboratorial alterations found in individuals co-infected with the human immunodeficiency virus (HIV) and the hepatitis C virus (HCV). Rev Bras Anal Clin. 2010;42:21-4

26. Pérez CM, Marrero E, Meléndez $M$, Adrovet $S$, Colón $H$, Ortiz AP, et al. Seroepidemiology of viral hepatitis, HIV and herpes simplex type 2 in the household population aged 21-64 years in Puerto Rico. BMC Infect Dis. 2010;10:76.

27. Sampaio AS, de Alencar L, Cláudio L, de Moura P, de Barros Correia J, de Barros Barreto $S$, et al. Prevalence of co-infection with hepatitis B and C in HIV-positive patients and associated risk factors. SIDA. 2009;17:12-7.

28. Pérez CC, Cerón Al, Fuentes LG, Zañartu SC, Balcells MME, Ajenjo HC, Rabagliati BR, Labarca LJ, Acuña LG. Hepatitis B, C, Treponema pallidum and Toxoplasma gondii co-infections in HIV-infected patients. Rev Med Chil. 2009;137:641-8

29. Carvalho FH, Coêlho MR, Vilella Tde A, Silva JL, Melo HR. HIV/HCV coinfection at an university hospital in Recife, Brazil. Rev Saude Pub. 2009;43:133-9.

30. Ré V, Gallego S, Farías A, Barbás G, Kremer L, Díaz MP, et al. Hepatitis C and HIV coinfection in central region of Argentina: prevalence, genotype characterization and risk factors. Enferm Infecc Microbiol Clin. 2008;26:423-5.

31. Carmo RA, Guimarães MD, Moura AS, Neiva AM, Versiani JB, Lima LV, et al. The influence of HCV coinfection on clinical, immunological and virological responses to HAART in HIV-patients. Braz J Infect Dis. 2008;12:173-9.

32. Reiche EM, Bonametti AM, Morimoto HK, Morimoto AA, Wiechemann SL, Matsuo T, et al. Epidemiological, immunological and virological characteristics and disease progression of HIV-1/HCV-co-infected patients from a southern Brazilian population. Int J Mol Med. 2008;21:387-95.

33. dos Santos EO, Coêlho M, Villela T, Silva J, Neto E. Occurrence and risk factors for coinfection of hepatitis $\mathrm{C}$ virus $(\mathrm{HCV})$ in patients with human immunodeficiency virus (HIV) in Macéio, Brazil. Rev Para Med. 2008;22:23-9.

34. Alfonso AP, Corcho AR, Monzón VH, Jam Morales BC, Jiménez YB, Cabanes $\mathrm{P}$, et al. Coinfección VIH-hepatitis B y C en la provincia de Cienfuegos/HIV/ hepatitis B and C co-infection in Cienfuegos province. Rev Cuba Med Trop. 2008;60:141-7.

35. Mussi AD, Pereira RA, Corrêa e Silva Vde A, Martins RM, Souto F. Epidemiological aspects of hepatitis $\mathrm{C}$ virus infection among HIV-infected individuals in Mato Grosso State, Central Brazil. Acta Trop. 2007;104:116-21.

36. Quarleri JF, Bolcic FM, Bouzas MB, Laufer N, Gómez Carrillo M, Mammana L, et al. HCV genotype distribution among HIV-co-infected individuals in Argentina: relationship with host and viral factors. Acta Gastroenterol Latinoam. 2007:37:76-83.

37. Rivas-Estilla AM, Ramírez-Valles E, Martinez-Hernández R, Charles-Niño C, Ramírez-Camacho E, Rositas-Noriega F, et al. Hepatitis C virus infection among HIV-1-infected individuals from northern Mexico. Hepatol Res. 2007:37:311-6.

38. Hoyos-Orrego A, Massaro-Ceballos M, Ospina-Ospina M, Gómez-Builes C, Vanegas-Arroyave N, Tobón-Pereira J, et al. Serological markers and risk factors for hepatitis $B$ and $C$ viruses in patients infected with human immunodeficiency virus. Rev Inst Med Trop Sao Paulo. 2006;48:321-6. 
39. Tovo CV, Dos Santos DE, de Mattos AZ, de Almeida PR, de Mattos AA, Santos BR. Ambulatorial prevalence of hepatitis B and C markers in patients with human immunodeficiency virus infection in a general hospital. Arq Gastroenterol. 2006:43:73-6.

40. de Carvalho F, Da Silva Melo A, de Lacerda H, Coêlho M. Prevalence of antiHCV among HIV-seropositive patients. Rev Para Med. 2006;20:11-3.

41. Bello Corredor M, Rodríguez Lay Lde L, Gutiérrez Moreno A, Sariego Frómeta S, Montalvo Villalba MC, Sánchez Sol A. Detection of hepatitis B and hepatitis C markers in HIV-positive patients, 2000-2004. Rev Cubana Med Trop. 2005;57:212-3.

42. Rodríguez ME, Llop A, Capó V, Kourí V, Resik S, Rojas L, et al. Human immunodeficiency virus and other sexually transmitted diseases in Cuban women. Clin Microbiol Infect. 2005;11:764-7.

43. De Los Angeles Pando M, Biglione MM, Toscano MF, Rey JA, Russell KL, Negrete $M$, et al. Human immunodeficiency virus type 1 and other viral coinfections among young heterosexual men and women in Argentina. Am J Trop Med Hyg. 2004;71:153-9.

44. Segurado AC, Braga P, Etzel A, Cardoso MR. Hepatitis C virus coinfection in a cohort of HIV-infected individuals from Santos, Brazil: seroprevalence and associated factors. AIDS Patient Care STDS. 2004;18:135-43.

45. Pavan MH, Aoki FH, Monteiro DT, Gonçales NS, Escanhoela CA, Gonçales Júnior FL. Viral hepatitis in patients infected with human immunodeficiency virus. Braz J Infect Dis. 2003;7:253-61.

46. Mendes-Corrêa MC, Barone AA, Guastini C. Hepatitis C virus seroprevalence and risk factors among patients with HIV infection. Rev Inst Med Trop Sao Paulo. 2001:43:15-9.

47. Treitinger A, Spada C, Silva EL, Miranda AF, Oliveira OV, Silveira MV, et al. Prevalence of serologic markers of HBV and HCV infection in HIV-1 seropositive patients in Florianópolis, Brazil. Braz J Infect Dis. 1999;3:1-5.

48. Fainboim H, González J, Fassio E, Martínez A, Otegui L, Eposto M, et al. Prevalence of hepatitis viruses in an anti-human immunodeficiency virus-positive population from Argentina. A multicentre study. J Viral Hepat. 1999:6:53-7.

49. Edelenyi-Pinto M, Carvalho AP, Nogueira C, Ferreira Júnior O, Schechter M. Prevalence of antibodies to hepatitis $C$ virus in populations at low and high risk for sexually transmitted diseases in Rio de Janeiro. Mem Inst Oswaldo Cruz. 1993:88:305-7.

50. Hyams KC, Phillips IA, Moran AY, Tejada A, Wignall FS, Escamilla J. Seroprevalence of hepatitis C antibody in Peru. J Med Virol. 1992;37:127-31.

51. Sherman KE, Rouster SD, Chung RT, Rajicic N. Hepatitis C virus prevalence among patients infected with human immunodeficiency virus: a crosssectional analysis of the US Adult AIDS Clinical Trials Group. Clin Infect Dis. 2002:34:831-7

52. Abdala N, Carney JM, Durante AJ, Klimov N, Ostrovski D, Somlai AM, et al. Estimating the prevalence of syringe-borne and sexually transmitted diseases among injection drug users in St Petersburg, Russia. Int J STD AIDS. 2003;14:697-703.

53. Thomas DL, Vlahov D, Solomon L, Cohn S, Taylor E, Garfein R, et al. Correlates of hepatitis $C$ virus infections among injection drug users in Baltimore. Medicine. 1995;74:212-20.

54. Lincoln D, Petoumenos K, Dore GJ. HIV/HBV and HIV/HCV coinfection and outcomes following highly active antiretroviral therapy. HIV Med. 2003:4:241-9.

55. Solomon SS, SriKrishnan AK, Mehta SH, Vasudevan CK, Murugavel KG,

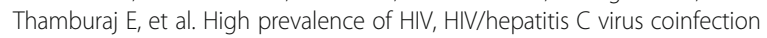
and risk behaviors among injection drug users in Chennai, India: a cause for concern. J Acquir Immune Defic Syndr. 2008;49:327-32.

56. Quan VM, Go VF, Nam LV, Bergenstrom A, Thuoc NP, Zenilman J, et al. Risks for HIV, HBV, and HCV infections among male injection drug users in northern Vietnam: a case-control study. AIDS Care. 2009;21:7-16.

57. Tan $Y$, Wei $\mathrm{QH}$, Chen $\mathrm{L}$, Chan PC, Lai WS, He ML, et al. Molecular epidemiology of HCV monoinfection and HIV/HCV coinfection in injection drug users in Liuzhou, Southern China. PLoS One. 2008:3:e3608.

58. Garten RJ, Lai S, Zhang J, Liu W, Chen J, Vlahov D, et al. Rapid transmission of hepatitis $C$ virus among young injecting heroin users in Southern China. Int J Epidemiol. 2004;33:182-8.

59. Greub G, Ledergerber B, Battegay M, Grob P, Perrin L, Furrer H, et al. Clinical progression, survival, and immune recovery during antiretroviral therapy in patients with HIV-1 and hepatitis C virus coinfection: the Swiss HIV Cohort Study. Lancet. 2000;356:1800-5.

60. Sulkowski MS, Moore RD, Metha SH, Chaisson RE, Thomas DL. Hepatitis C and progression of HIV disease. JAMA. 2002;288:199-206.
61. Nelson P, Mathers B, Cowie B, Hagan H, Jarlais DD, Horyniak D, Degenhardt $\mathrm{L}$. The epidemiology of viral hepatitis among people who inject drugs: Results of global systematic reviews. Lancet. 2011;378:571-83.

62. Gonçales NSL, Gonçales Junior FL. Laboratory testing for hepatitis C. Braz J Infect Dis. 2007;11 Suppl 1:22-4.

63. Pereira LM, Martelli CM, Moreira RC, Merchan-Hamman E, Stein AT, Cardoso MRA, et al. Prevalence and risk factors of Hepatitis C virus infection in Brazil, 2005 through 2009: a cross-sectional study. BMC Infect Dis. 2013;13:60.

\section{Submit your next manuscript to BioMed Central and we will help you at every step:}

- We accept pre-submission inquiries

- Our selector tool helps you to find the most relevant journal

- We provide round the clock customer support

- Convenient online submission

- Thorough peer review

- Inclusion in PubMed and all major indexing services

- Maximum visibility for your research

Submit your manuscript at www.biomedcentral.com/submit
Biomed Central 